\title{
Pelarutan Besi Selektif pada Korosi Baja Karbon dalam Larutan Buffer Asetat, Natrium Bikarbonat - $\mathrm{CO}_{2}$ Jenuh
}

\author{
Bunbun Bundjali, N.M. Surdia, Oei Ban Liang \& Bambang Ariwahjoedi
}

Departemen Kimia FMIPA Institut Teknologi Bandung

Jl. Ganesha 10 Bandung 40132

\begin{abstract}
Sari. Telah diselidiki kondisi yang memungkinkan terjadinya korosi jenis sumuran pada baja karbon dalam larutan uji berupa larutan pH 3,82; 4,12 ; 5,12 dan 6,12 buffer asetat, larutan 0,2 M NaOAc dan larutan air laut standar, yang semuanya mengandung $100 \mathrm{mg}$ natrium bikarbonat/L dan jenuh $\mathrm{CO}_{2}$. Laju korosi ditentukan dengan cara corrosion wheel test dan corrosion bubble test, morfologi permukaan diamati dengan mikroskop elektron (SEM) dan mikroskop optik metalografi, sedangkan kerusakan permukaan dan struktur kisi baja karbon terkorosi diikuti dengan pengamatan pola difraksi sinar-X (XRD). Pola difraksi sinar-X baja karbon yang terkorosi dalam semua larutan uji di atas, memperlihatkan pengurangan intensitas relatif pada bidang kisi 110 dan 200 serta peningkatan pada bidang kisi 211. Besarnya penurunan intensitas difraksi sinar-X ini meningkat dengan bertambahnya \% pengurangan berat kupon baja karbon terkorosi, menunjukkan terjadinya pelarutan selektif atom besi yang terletak pada kedua bidang kisi tersebut. Hal ini diduga disebabkan karena bidang kisi 211 memiliki \% keterisian atom besi terkecil di antara ketiga bidang kisi itu, maka berpeluang terbesar untuk disisipi atom karbon yang akan memberikan efek perlindungan terhadap atom besi-nya untuk tidak melarut. Walaupun proses korosi dimulai dari fasa permukaan, ternyata pola difraksi sinar-X dari ketiga bidang kisi tersebut dapat dijadikan indikator korosi pada baja karbon, karena itu kinerja suatu inhibitor korosi dapat dilihat dari kemampuannya dalam mempertahankan pola difraksi baja karbon semula.
\end{abstract}

Kata kunci: baja karbon; buffer asetat; korosi sumuran; natrium bikarbonat - $\mathrm{CO}_{2}$; pelarutan besi selektif; $X \boldsymbol{R D}$
Abstract. This work has investigate conditions which allow pitting corrosion of carbon steel in acetate buffered test solutions of $\mathrm{pH}$ 3.82, 4.12, 5.12 and 6.12, 0.2 $\mathrm{M} \mathrm{NaOAc}$ and standard brine solutions, all of which contains $100 \mathrm{mg} / \mathrm{L}$ sodium bicarbonate and saturated with $\mathrm{CO}_{2}$. Corrosion rates is determined by corrosion wheel and corrosion bubble tests, while surface morphology is observed by electron microscopy (SEM) and metallographic optical microscopy, whereas surface deterioration as well as corroded lattice structure of the steel is monitored through measurements by X-ray Diffraction (XRD) patterns. The X- ray Diffraction Patterns of corroded carbon steel in any of the above test solutions exhibit a decrease in relative intensity of 110 and 200 lattice planes and an increase in the 211 lattice plane. The extent of decrease of the diffracted X- ray intensities increases with the increase in the percentage of corroded carbon

Makalah diterima redaksi tanggal 25 April 2005, revisi diterima tanggal 25 Juli 2006. 
steel coupon weight loss. This might reflect a selective dissolution of iron atoms situated in both lattice planes. It is suspected that this observation is due to the fact that 211 lattice plane has the smallest percentage of atomic occupancy among the three, thus it might have the greatest chance to be inserted with carbon atoms which in turn gives a protective effect toward iron atoms against further dissolution. Although, the corrosion process starts from the surface phase, this experiment reveals that X-ray diffraction pattern of the three lattice planes could be employed as some sort of carbon steel corrosion indicator. Consequently, corrosion inhibitor performance could be deduced from its ability to maintain diffraction pattern of the initial carbon steel specimen.

Keywords: acetate buffer; carbon steel; pitting corrosion; selective iron dissolution; sodium - bicarbonate- $\mathrm{CO}_{2}$; XRD.

\section{Pendahuluan}

Hampir semua kerusakan pada bagian dalam jaringan pipa baja karbon penyalur minyak mentah dan gas alam disebabkan oleh korosi lokal, korosi jenis mesa, atau korosi pada bagian langit-langit dalam pipa (top of line corrosion, TLC). Korosi terlokalisasi ini diakibatkan oleh tercegahnya pembentukan atau rusaknya lapisan kerak karbonat /oksida logam dan/atau lapisan inhibitor korosi pada permukaan baja karbon yang berfungsi sebagai pelindung terhadap korosi lebih lanjut $[1,2,3]$. Sesudah terinisiasi, laju penetrasi korosi jenis ini dapat mencapai puluhan kali lipat dari korosi jenis seragam yang pada umumnya berlaju kurang dari $0,2 \mathrm{~mm} / \mathrm{th}$.

Kehadiran ion asetat dalam aliran minyak mentah dan gas alam menyebabkan peningkatkan laju korosi baja karbon, karena kemampuannya dalam menurunkan $\mathrm{pH}$ dan melarutkan $\mathrm{Fe}^{2+}$ pada selaput besi karbonat. Perusakan lokal selaput ini akan memicu korosi terlokalisasi [4,5,6]. Pada korosi $\mathrm{CO}_{2}$ terhadap baja karbon, ion bikarbonat $\left(\mathrm{HCO}_{3}^{-}\right)$secara serentak menjadi buffer asam karbonat $\left(\mathrm{H}_{2} \mathrm{CO}_{3}\right)$, dan sumber karbonat untuk pengendapan besi karbonat $\left(\mathrm{FeCO}_{3}\right)$. Selain itu diduga sebagai hasil lain dari korosi baja karbon adalah lapisan sementit, $\mathrm{Fe}_{3} \mathrm{C}$. Berbeda dengan lapisan $\mathrm{FeCO}_{3}$ yang bersifat sebagai isolator, $\mathrm{Fe}_{3} \mathrm{C}$, masih berperan sebagai konduktor dan menjadi tempat berlangsungnya reaksi katodik. Karenanya memungkinkan adanya kopling galvanik lateral antar fasa baja karbon dan lapisan sementit $\left(\mathrm{Fe}_{3} \mathrm{C}\right)$ yang dapat memfasilitasi terjadinya korosi terlokalisasi $[7,8,9]$.

Penelitian ini bertujuan mengamati lebih lanjut pengaruh $\mathrm{pH}$ terhadap laju korosi baja karbon dalam lingkungan buffer asetat, bikarbonat $-\mathrm{CO}_{2}$ jenuh. Kerusakan permukaan dan mikrostruktur diamati dengan analisis SEM (Scanning Electron Mikroscope) dan mikroskop metalografi. Sedangkan teknik analisis XRD ( $X$-ray Diffraction) digunakan untuk analisis fasa permukaan dan 
fasa ruah terhadap baja karbon sebelum dan sesudah terkorosi serta efek penggunaan inhibitor terhadap korosi baja karbon dalam lingkungan di atas.

\section{Bahan dan Cara Kerja}

\subsection{Sampel Baja Karbon, Larutan Uji dan Inhibitor Korosi}

Digunakan sampel kupon baja karbon berukuran $2 \times 1 \times 0,05 \mathrm{~cm}$. Komposisi (dalam \% berat) material ini selain besi adalah: C 0,1; P 0,025; Mn 0,45 dan S 0,03. Larutan uji adalah larutan buffer asetat yang mengandung $100 \mathrm{mg}$ natrium bikarbonat/L dengan $\mathrm{pH} 4,12 ; 5,12$ dan 6,12 pada $[\mathrm{NaOAc}]=0,2 \mathrm{M}$, berdaya hantar sekitar $12 \mathrm{mS} / \mathrm{cm}$. Sebagai larutan uji pembanding digunakan larutan 0,2 M NaOAc dan larutan standar air laut, $3 \% \mathrm{NaCl}$, juga mengandung $100 \mathrm{mg}$ natrium bikarbonat/L larutan. Penjenuhan gas $\mathrm{CO}_{2}$ dengan cara bubbling ke dalam larutan uji, menggunakan gas $\mathrm{CO}_{2}$ dengan kemurnian $>99,9 \%$. Inhibitor yang dievaluasi kinerjanya adalah Oleyl Hydroxy Ethyl Imidazoline (OHEI, surfaktan kationik), Hexadecyl Succinic Anhydride (HDSA, inhibitor standard lab. untuk korosi $\mathrm{CO}_{2}$ ), Monoalkil fosfat (MAP, surfaktan anionik) dan suatu inhibitor korosi komersial (IKK, campuran dua atau lebih senyawa inhibitor).

\subsection{Cara Kerja}

\subsubsection{Penentuan Laju Korosi Dengan Cara Corrosion Wheel Test}

Kupon baja karbon dibersihkan dengan diampelas basah menggunakan silikon karbida (SiC, sampai 800 grit), kemudian direndam dalam etanol. Berat kupon kering sebelum dan sesudah terkorosi ditimbang sampai ketelitian 0,1 mg. Eksperimen dilakukan dalam botol gelas bervolume $225 \mathrm{~mL}$, diisi dengan 200 $\mathrm{mL}$ larutan uji yang dijenuhkan dengan $\mathrm{CO}_{2}$ dan dibebaskan dari oksigen terlarut dengan pengaliran bubbling gas $\mathrm{CO}_{2}$ selama 60 menit. Corrosion wheel test dilakukan pada suhu $65^{\circ} \mathrm{C}$, selama 6, 12, 24, 42, dan 72 jam.

\subsubsection{Analisis Permukaan dan Fasa Ruah dengan SEM dan XRD}

Untuk keperluan analisis dengan SEM dan XRD, sampel kupon sesudah corrosion wheel test tidak dicuci, hanya dikeringkan dengan kertas penyerap saja. Kupon ini langsung digunakan untuk pengukuran analisis fasa dengan XRD. Pola difraksi sinar-X terhadap kupon sebelum dan sesudah corrosion wheel test - tanpa dan dengan penambahan berbagai inhibitor korosi pada berbagai konsentrasi dan berbagai waktu kontak - dilakukan secara ex-situ dengan menggunakan Diffraktometer Siemens D500. Kondisi pengukuran adalah sebagai berikut: sumber sinar X Cu Ka 1,5405 $\AA, 40 \mathrm{kV}$ dan $30 \mathrm{~mA}$; menggunakan diskriminator penganalisis pulsa detektor NaI, selang pindaian peningkatan $2 \theta=0,02^{\circ}$, kecepatan pembacaan $1,2^{\circ}$ /menit. Untuk analisis penampang lintang lapisan korosi dengan teknik SEM, kupon dipancangkan 
dalam resin epoksi, kemudian dipoles sampai mencapai kehalusan permukaan sekitar $1 \mu \mathrm{m}$, lalu dilapisi dengan logam emas. Pengamatan citra penampang lintang permukaan terkorosi dan lapisan hasil korosi, dilakukan dengan menggunakan SEM merk Philips XL 30, yang dioperasikan pada tegangan 20 $\mathrm{kV}$, dengan pembesaran $500 \mathrm{x}$ sampai $2000 \mathrm{x}$. Fotomikrostruktur permukaan kupon baja karbon tak terkorosi dan yang terkorosi sesudah corrosion wheel test (sesudah dipoles) dilakukan dengan mikroskop metalografi dengan pembesaran $500 \mathrm{x}$.

\section{Hasil dan Pembahasan}

\subsection{Analisis corrosion wheel test}

Hasil corrosion wheel test baja karbon dalam larutan buffer asetat pada berbagai $\mathrm{pH}$, dibandingkan dengan dalam air laut standar dan larutan 0,2 M NaOAc pada $65^{\circ} \mathrm{C}$, ditunjukkan pada Gambar 1. Tampak bahwa laju korosi tinggi terjadi pada waktu kontak 6 jam pertama, hal ini berkaitan dengan permukaan sampel baja karbon yang masih belum terselimuti lapisan hasil korosi dan konsentrasi pereaksi yang masih tinggi. Laju korosi baja karbon dalam larutan buffer $\mathrm{pH} 4$, hampir tetap sekitar 4,9 mm/th. Sedangkan untuk larutan dengan $\mathrm{pH} \geq 5$, laju korosi berkurang dengan bertambahnya waktu kontak, karena terbentuknya selaput pelindung yang menghambat korosi lebih lanjut. Lapisan selaput pelindung tersebut kemungkinan tidak dapat terbentuk atau melarut kembali pada $\mathrm{pH}<5$.

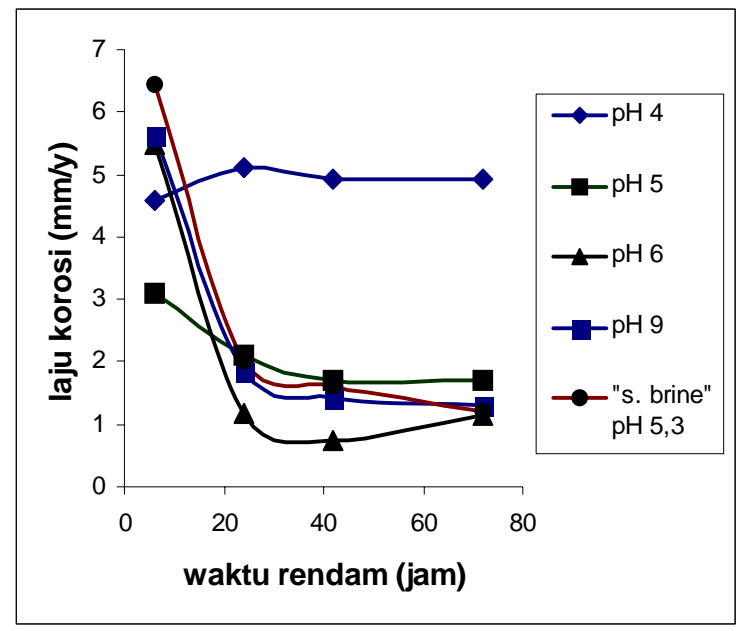

Gambar 1 Pengaruh waktu perendaman pada $65^{\circ} \mathrm{C}$ "corrosion wheel test", terhadap laju korosi baja karbon dalam larutan buffer asetat pada berbagai $\mathrm{pH}$ ([NaOAc] tetap 0,2 M), dibandingkan dengan dalam air laut standar, dan dalam larutan 0,2 M NaOAc. 


\subsection{Analisis Penampang Lintang Kupon Sesudah Corrosion Bubble Test}

Pengamatan citra SEM memperlihatkan bahwa kupon baja karbon yang terendam secara statik dalam larutan buffer asetat $\mathrm{pH}$ 3,82 yang mengandung $100 \mathrm{mg} / \mathrm{L}$ natrium bikarbonat dan jenuh $\mathrm{CO}_{2}$ (dengan pengaliran gas ini secara menerus) pada suhu $65^{\circ} \mathrm{C}$, lebih cenderung terkorosi lokal, jenis sumuran sebagai tampak pada Gambar 2. Bertambah lamanya waktu perendaman dari 24 jam s/d 72 jam meningkatkan kerapatan dan kedalaman sumuran korosi yang terjadi. Pada waktu rendam 24 jam, pengurangan berat kupon baja karbon adalah 4,89 \%, dengan kedalaman lubang korosi sumuran sekitar $80 \mu \mathrm{m}$ dan lebar lubang pada permukaan sekitar $70 \mu \mathrm{m}$. Sedangkan dengan waktu rendam 72 jam, pengurangan berat kupon menjadi 18,2\%, dengan kedalaman lubang korosi sumuran menjadi $160 \mu \mathrm{m}$ dan tampak pula terjadinya pelebaran ukuran masing-masing lubang sehingga dua lubang yang berdekatan menjadi bersentuhan. Dari kenyataan ini maka laju korosi yang dinyatakan sebagai $\mathrm{mm} / \mathrm{th}$ adalah lebih tepat untuk korosi seragam, karena untuk korosi terlokalisasi jenis sumuran, walaupun pengurangan \% berat baja karbon yang terkorosi dalam larutan buffer asetat, bikarbonat - jenuh $\mathrm{CO}_{2}$ pada $\mathrm{pH}$ 3,82 dan suhu $65^{\circ} \mathrm{C}$, masih berbanding langsung dengan lamanya waktu perendaman, namun penetrasi / penipisan logam tidak merata pada seluruh permukaan logam.

Hasil eksperimen ini menunjukkan bahwa korosi lokal jenis sumuran dapat terjadi pada baja karbon dalam lingkungan asam asetat - ion asetat jenuh $\mathrm{CO}_{2}$ atau bebas oksigen pada suhu sekitar $65^{\circ} \mathrm{C}$, dalam kondisi aliran fluida bersifat laminar atau statik. Larutan uji yang memungkinkan korosi tersebut berlangsung dengan cepat adalah pada $\mathrm{pH} \sim 3,82-4,12$; yaitu kondisi yang akan mencegah terbentuknya lapisan kerak karbonat/logam oksida pelindung dan mendorong terbentuknya besi asetat yang berpori dengan kelarutan tinggi. Kondisi yang mirip dengan eksperimen ini mungkin dapat terjadi dalam pipa jaringan penyalur minyak dan gas alam yang menyembul melengkung dari dasar sungai, pada bagian ini dapat terjadi peningkatan konsentrasi asam asetat pada bagian langit-langitnya, karena proses pengembunan uap air yang mengandung asam asetat oleh dinginnya air sungai di bagian luar pipa. Peningkatan konsentrasi ini ditunjang oleh laju alir yang lebih lambat, fluktuasi suhu dan berkurangnya jangkauan inhibitor (terlarut pada fasa air) memungkinkan terjadinya korosi lokal sumuran pada bagian langit-langit pipa. Sekalipun terjadi aliran turbulensi pada bagian ini, hanya akan menghilangkan selaput kerak karbonat dan/atau keberadaan lapisan molekul inhibitor, sehingga bila terdapat asam asetat yang terjebak/terakumulasi akan mampu meningkatkan keasaman lokal, walaupun waktu keberadaannya singkat-singkat namun sudah cukup untuk menjadi pemicu korosi terlokalisasi yang akan berkembang menjadi korosi sumuran. Selanjutnya korosi sumuran yang terbangkitkan pada 
baja karbon dalam larutan ber-pH rendah tidak mengalami repasifasi dan akan tumbuh menjadi daerah yang rentan terhadap penjalaran rengkahan dengan mekanisme transisi sumuran ke retakan korosi tegangan transgranuler sebagaimana disimpulkan oleh Park dkk. [10].

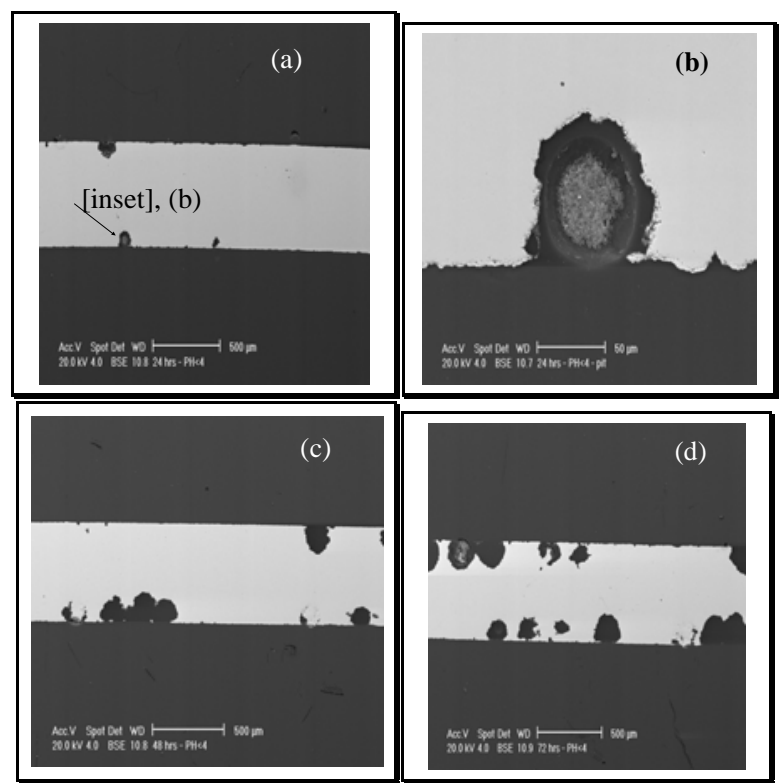

Gambar 2 Citra SEM penampang lintang kupon baja karbon sesudah "corrosion bubble test" dalam larutan buffer asetat $\mathrm{pH}$ 3,82 yang mengandung $100 \mathrm{mg} / \mathrm{L}$ natrium bikarbonat dan jenuh $\mathrm{CO}_{2}$ pada suhu $65^{\circ} \mathrm{C}$ : (a) $24 \mathrm{jam}$ perendaman, (b) inset sumuran pada (a), (c) 48 jam perendaman, dan (d) 72 jam perendaman.

\subsection{Analisis Fasa Kupon Corrosion Wheel Test dengan XRD dan Mikro-Struktur}

Gambar 3 menampilkan difraktogram baja karbon sesudah corrosion wheel test dalam larutan buffer asetat $\mathrm{pH} 4 \mathrm{~s} / \mathrm{d}$ 6, larutan 0,2 M NaOAc $(\mathrm{pH}=9,03)$ dan larutan standar air laut $(\mathrm{pH}=5,3)$ yang dijenuhi $\mathrm{CO}_{2}$ pada suhu $65^{\circ} \mathrm{C}$. Selain munculnya puncak-puncak dengan intensitas rendah yang berasal dari lapisan hasil korosi, tampak bahwa pola difraktogram hampir serupa, dengan intensitas tertinggi terjadi pada $2 \theta \sim 82,333^{\circ}$, yaitu, berasal dari bidang 211 pada kisi baja. Pola ini berbeda dengan difraktogram baja tak terkorosi. Pola difraktogram karakteristik untuk besi murni (dengan sumber sinar-X $\mathrm{CuK \alpha} \alpha$ ) terutama ditunjukkan oleh 3 puncak dengan intensitas terkuat yaitu pada sudut - sudut

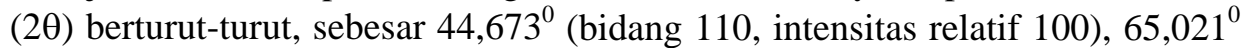
(bidang 200, intensitas relatif 20) dan $82,333^{\circ}$ (bidang 211, intensitas relatif 30 ). Pengaruh korosi dan lamanya waktu perendaman - dalam larutan $\mathrm{pH} 4$ buffer 
asetat, larutan 0,2 M NaOAc dan air laut standar - terhadap intensitas ketiga puncak terkuat pada difraktogram XRD ditunjukkan pada Gambar 4 dan Tabel 1. Tampak bahwa dengan bertambahnya waktu perendaman, baik dalam larutan $\mathrm{pH} 4$ buffer asetat maupun dalam air laut standar, intensitas difraksi bidang 110 dan 200 terus berkurang, sedangkan intensitas difraksi relatif yang berasal dari bidang 211 menjadi yang terkuat. Selain itu tampak pula dengan meningkatnya suhu dari $65^{\circ} \mathrm{C}$ ke $85^{\circ} \mathrm{C}$ pada perendaman dalam larutan $0,2 \mathrm{M} \mathrm{NaOAc}$, pengurangan intensitas kedua bidang tersebut semakin membesar dan ini sejalan dengan meningkatnya laju korosi atau pengurangan berat pada sampel kupon baja karbon.

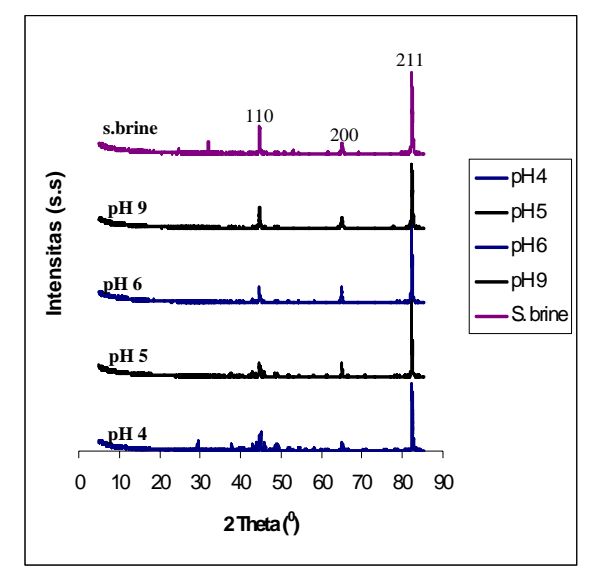

Gambar 3 Difraktogram kupon baja karbon sesudah 24 jam corrosion wheel test dalam berbagai $\mathrm{pH}$ larutan buffer asetat dan air laut standar, $65^{\circ} \mathrm{C}$.

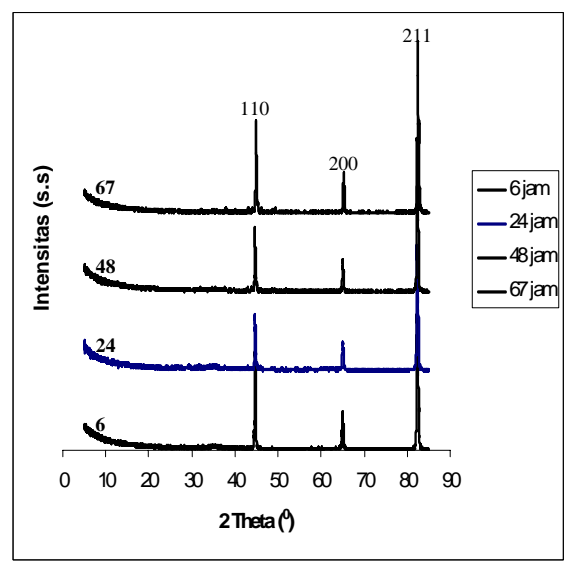

Gambar 4 Difraktogram kupon baja karbon sesudah 6 s/d 67 jam corrosion bubble test dalam larutan buffer asetat $\mathrm{pH} 3,82$ jenuh $\mathrm{CO}_{2}$ pada suhu $65^{\circ} \mathrm{C}$. 
Tabel 1 Pengaruh waktu perendaman dan suhu terhadap tiga garis terkuat pada pola XRD baja karbon yang terkorosi pada berbagai larutan uji, besi sintetik (standar), dan sampel baja karbon sebelum terkorosi.

\begin{tabular}{|c|c|c|c|c|c|c|c|c|c|c|}
\hline Bidang & \multicolumn{2}{|c|}{$\begin{array}{l}\text { Besi sintetik } \\
\text { PDF\#06-0696 }\end{array}$} & \multicolumn{2}{|c|}{$\begin{array}{l}\text { Baja karbon } \\
\text { sebelum } \\
\text { terkorosi }\end{array}$} & \multicolumn{6}{|c|}{$\begin{array}{c}\text { Baja karbon terkorosi dalam larutan pH } 4 \\
\text { buffer asetat, bikarbonat- } \mathrm{CO}_{2} \text { jenuh, } 65^{\circ} \mathrm{C} \\
\text { dengan lama waktu rendam }\end{array}$} \\
\hline \multirow[b]{2}{*}{$h k l$} & \multirow{2}{*}{$\begin{array}{l}2 \theta \\
\left({ }^{0}\right)\end{array}$} & \multirow{2}{*}{$\begin{array}{l}\mathrm{I}_{\mathrm{r}} \\
(\%)\end{array}$} & \multirow{2}{*}{$\begin{array}{l}2 \theta \\
(0)\end{array}$} & \multirow{2}{*}{$\begin{array}{l}\mathrm{I}_{\mathrm{r}} \\
(\%)\end{array}$} & \multicolumn{2}{|c|}{6 jam } & \multicolumn{2}{|c|}{48 jam } & \multicolumn{2}{|c|}{72 jam } \\
\hline & & & & & $2 \theta\left(^{0}\right)$ & $\begin{array}{l}\mathrm{I}_{\mathrm{r}} \\
(\%)\end{array}$ & $2 \theta\left(^{0}\right)$ & $\begin{array}{c}\mathrm{I}_{\mathrm{r}} \\
(\%)\end{array}$ & $2 \theta\left({ }^{0}\right)$ & $\begin{array}{l}\mathrm{I}_{\mathrm{r}} \\
(\%)\end{array}$ \\
\hline 110 & 44,67 & 100 & 44,40 & 100 & 44,80 & 57,4 & 44,80 & 51,7 & 44,58 & 39,5 \\
\hline 200 & 65,02 & 20 & 64,72 & 11,3 & 65,14 & 23,2 & 65,21 & 20,7 & 64,92 & 18,0 \\
\hline 211 & 82,33 & 30 & 82,08 & 27,8 & 82,40 & 100 & 82,43 & 100 & 82,26 & 100 \\
\hline \multicolumn{5}{|c|}{$\begin{array}{l}\text { Baja karbon terkorosi dalam larutan } \\
\text { 0,2M NaOAc, bikarbonat- } \mathrm{CO}_{2} \text { jenuh, } \\
\text { waktu rendam } 72 \text { jam, pada suhu }\end{array}$} & \multicolumn{6}{|c|}{$\begin{array}{c}\text { Baja karbon terkorosi dalam larutan air laut } \\
\text { standar, bikarbonat- } \mathrm{CO}_{2} \text { jenuh, } 65^{\circ} \mathrm{C} \text {, dengan } \\
\text { lama waktu rendam }\end{array}$} \\
\hline Bidang & \multicolumn{2}{|c|}{$65^{\circ} \mathrm{C}$} & \multicolumn{2}{|c|}{$85^{\circ} \mathrm{C}$} & \multicolumn{2}{|c|}{6 jam } & \multicolumn{2}{|c|}{48 jam } & \multicolumn{2}{|c|}{$72 \mathrm{jam}$} \\
\hline$h k l$ & $2 \theta\left({ }^{0}\right)$ & $\begin{array}{l}\mathrm{I}_{\mathrm{r}} \\
(\%)\end{array}$ & $2 \theta\left(^{0}\right)$ & $\begin{array}{l}\mathrm{I}_{\mathrm{r}} \\
(\%)\end{array}$ & $2 \theta\left(^{0}\right)$ & $\begin{array}{l}\mathrm{I}_{\mathrm{r}} \\
(\%)\end{array}$ & $2 \theta\left({ }^{0}\right)$ & $\begin{array}{l}\mathrm{I}_{\mathrm{r}} \\
(\%)\end{array}$ & $2 \theta\left(^{0}\right)$ & $\begin{array}{l}\mathrm{I}_{\mathrm{r}} \\
(\%)\end{array}$ \\
\hline 110 & 44,78 & 38,5 & 44,46 & 34 & 44,66 & 62 & 44,64 & 40,8 & 44,68 & 34,6 \\
\hline 200 & 65,10 & 23,8 & 64,84 & 21,4 & 64,98 & 25,5 & 65,00 & 20,2 & 65,00 & 20,5 \\
\hline 211 & 82,40 & 100 & 82,17 & 100 & 82,34 & 100 & 82,32 & 100 & 82,32 & 100 \\
\hline
\end{tabular}

Sesuai dengan pola difraksi standar logam besi berstruktur kisi kristal kubus berpusat badan, sebagai tampak pada Gambar 5, bidang kisi 110 adalah yang memiliki kerapatan terbesar dalam keterisian posisi ruang atom-atom besi . Hal ini terbukti dari pola difraksi sinar-X besi murni, intensitas difraksi yang berasal dari bidang 110 adalah yang paling kuat (intensitas relatif 100\%). Berdasarkan difraktogram hasil percobaan ini, menunjukkan bahwa pada korosi baja karbon oleh asam asetat-ion asetat ataupun bikarbonat- $\mathrm{CO}_{2}$ bebas oksigen, keboleh jadian pelarutan besi terbesar adalah dari atom-atom besi yang berasal dari bidang 110 ini, karena terbanyak populasi atom besinya dan diduga paling mudah dilepaskan dibandingkan dengan atom-atom besi yang mewakili posisi bidang-bidang lainnya. Hal ini dapat dikaitkan dengan \% keterisian bidang kisi tersebut oleh atom besi yang ditunjukkan pada Gambar 5, bidang 110 dengan \% keterisian atom besi terbesar memiliki kecenderungan terkecil mengalami penyisipan atom karbon, sebaliknya bidang 211 yang \% keterisian atom besinya terkecil berpeluang besar tersisipi atom karbon. Kehadiran atom karbon ini sebagaimana halnya pada pembentukan $\mathrm{Fe}_{3} \mathrm{C}$, akan memberikan efek perlindungan terhadap pelepasan atom besi dari bidang ini pada proses korosi baja karbon. Hal ini sejalan dengan yang dikemukakan oleh Mora-Mendoza dan 
Turgoose [7] dan Gulbrandsen dkk. [8] yang menyimpulkan bahwa pada proses korosi baja karbon terjadi peningkatan luas permukaan residu $\mathrm{Fe}_{3} \mathrm{C}$ yang tak teroksidasi. Fotomikrostruktur yang ditunjukkan pada Gambar 6 memperkuat kesimpulan ini. Sebagai tampak pada Gambar 6, struktur mikro sampel baja karbon berupa besi karbida, $\left(\mathrm{Fe}_{3} \mathrm{C}\right.$, sementit), yang terdispersi dalam matrik ferrite. Sehingga patut diduga bahwa pada proses korosi ini bidang (110) pada kisi sel satuan yang satu bertindak sebagai anoda dan bidang (211) pada sel satuan yang lainnya bertindak sebagai katoda. Hal ini sejalan dengan yang dikemukakan oleh Crolet, JL dkk. [9] bahwa antara baja (ferrite) dan $\mathrm{Fe}_{3} \mathrm{C}$ dapat terjadi penggandengan galvanik (galvanic kopling) secara lateral yang memungkinkan terjadinya korosi terlokalisasi.

\% keterisian penampang bidang kisi oleh atom besi:

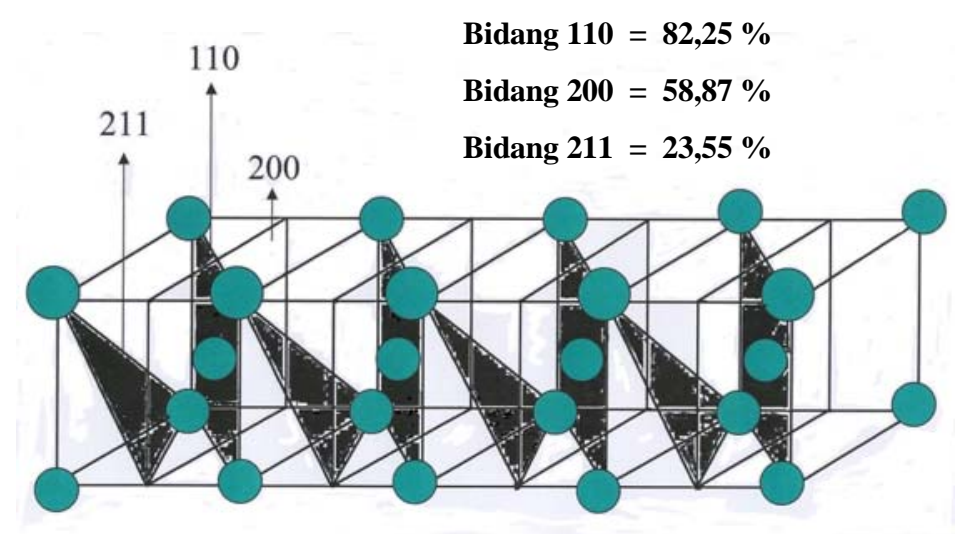

Gambar 5 Bidang-bidang sejajar (110, 200, dan 211) pendifraksi pada kisi logam besi (kubus berpusat badan, bcc).

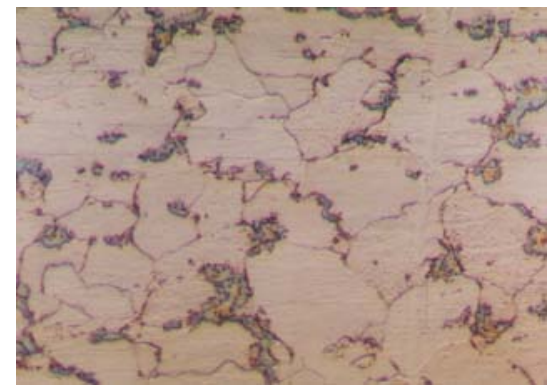

(a)

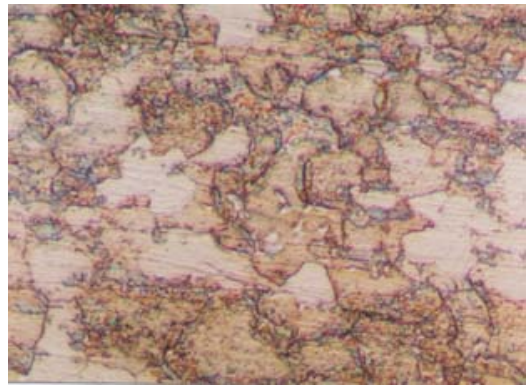

(b)

Gambar 6 Fotomikrostruktur (pembesaran 500 x) kupon baja karbon setelah dipoles a) sebelum terkorosi, dan b) sesudah terkorosi 


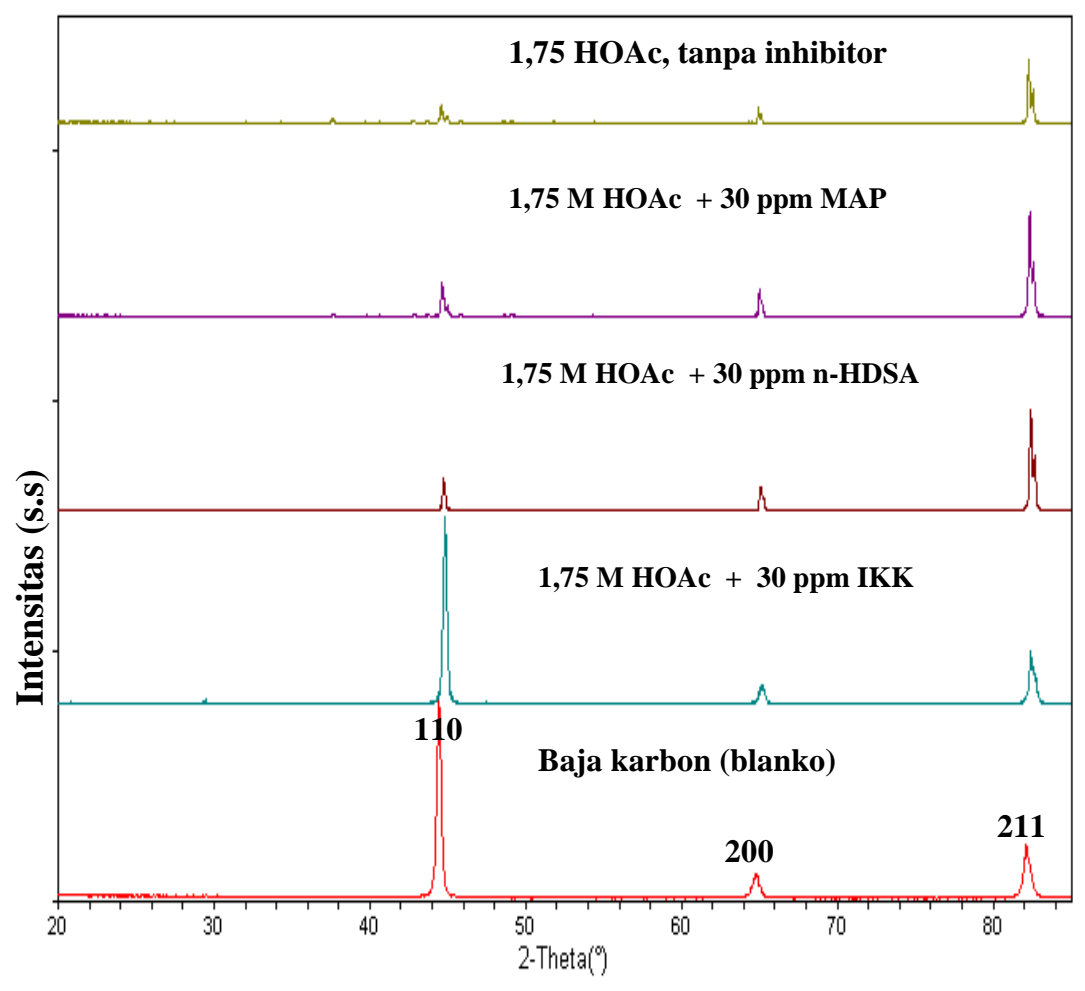

Gambar 7 Difraktogram kupon baja karbon (blanko) dan sesudah 24 jam corrosion wheel test dalam larutan 10\% HOAc yang mengandung $100 \mathrm{mg} / \mathrm{L}$ natrium bikarbonat - jenuh $\mathrm{CO}_{2}$, tanpa dan dengan 30 ppm inhibitor MAP dan IKK pada $85^{\circ} \mathrm{C}$ dan $30 \mathrm{ppm}$ n-HDSA pada $65^{\circ} \mathrm{C}$.

Data pola difraksi sinar-X yang dikemukakan di atas menunjukkan bahwa pelarutan besi pada korosi baja karbon dalam lingkungan buffer asetat, bikarbonat $-\mathrm{CO}_{2}$ jenuh bersifat selektif. Adanya kerusakan pada bagian dalam kisi kristal baja (bukan hanya pada permukaan saja) ini, patut menjadi perhatian dalam eksperimen elektrokimia yang sering kali menggunakan suatu elektroda kerja secara berulang kali, karena kerusakan itu dapat berpengaruh terhadap sifat elektrokimianya.

Gambar 7 menunjukkan bahwa, korosi baja karbon dalam lingkungan 10\% asam asetat (atau 1,75 M HOAc) yang mengandung $100 \mathrm{mg} / \mathrm{L}$ natrium bikarbonat dan jenuh $\mathrm{CO}_{2}$, menimbulkan kerusakan pada kisi besi yang tampak dari perubahan pola intensitas pada difraktogramnya. Sesuai dengan hasil 24 jam corrosion wheel test, korosi baja karbon dalam lingkungan tersebut pada suhu $85^{\circ} \mathrm{C}$ menyebabkan pengurangan berat sebesar $41,22 \%$, sedangkan 
dengan adanya $30 \mathrm{ppm}$ inhibitor laju korosi berkurang berturut-turut menjadi sekitar 20\% dengan MAP dan menjadi 0,49\% dengan IKK. Sedangkan pada suhu $65^{\circ} \mathrm{C}$, kehadiran $30 \mathrm{ppm}$ n-HDSA tidak memberikan efek inhibisi korosi, laju korosi tetap sekitar 19\% pengurangan berat dalam waktu 24 jam pengujian. Berdasarkan intensitas bidang-bidang kisi besi tersebut pada difraktogram blanko baja karbon dan pada kupon baja karbon sesudah corrosion wheel test tanpa dan dengan inhibitor - tampak bahwa proses korosi lebih banyak merusak atom-atom besi pada bidang (110), dan melindungi yang berada pada bidang (211). Tampak bahwa suatu inhibitor yang berfungsi secara efektif, memperlihatkan daya perlindungan terhadap korosi yang ditunjukkan oleh pola difraksi kupon uji yang relatif tidak berubah dari pola difraksi baja karbon semula. Gambar 8 memperlihatkan fotomikrostruktur permukaan baja karbon terkorosi sesudah corrosion weight loss dalam larutan 0,175 M HOAc, 0,1 M NaOAc, 0,1M NaHCO $3-$ jenuh $\mathrm{CO}_{2}$, pada suhu $85^{\circ} \mathrm{C}$, tanpa dan dengan 100 ppm inhibitor IKK.

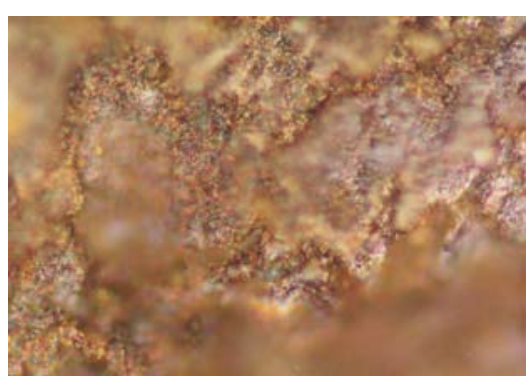

(a)

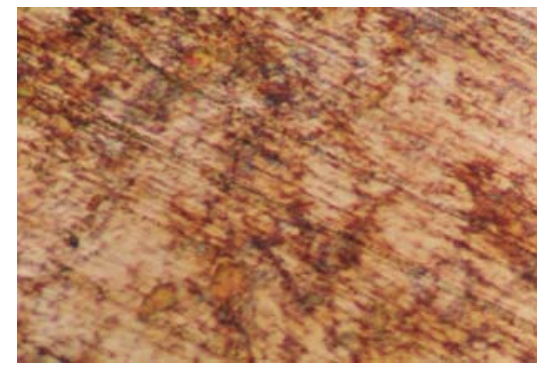

(b)

Gambar 8 Fotomikrostruktur (pembesaran 500 x) permukaan kupon baja karbon setelah corrosion weight loss dalam larutan 0,175 M HOAc, 0,1 M NaOAc, 0,1M NaHCO 3 - jenuh $\mathrm{CO}_{2}$, pada suhu $85^{\circ} \mathrm{C}$, tanpa dipoles (a) tanpa inhibitor, dan (b) dengan 100 ppm IKK.

Efek penggunaan inhibitor tersebut dapat diperbandingkan dengan salah satu cara lain untuk mencegah korosi baja karbon dalam sistem air umpan dan boiler pada PLTD yaitu dengan perlakuan oksigen (Oxygenated Treatment, $\mathrm{pH}$ 8,9; suhu $165-215^{\circ} \mathrm{C}$, tekanan 0,9 $-7 \mathrm{MPa}$ dan kandungan oksigen terlarut $50-200 \mu \mathrm{g} / \mathrm{L}$ ), [11]. Pada kondisi ini, selaput oksida besi berupa $\mathrm{Fe}_{3} \mathrm{O}_{4}$ dan $\mathrm{Fe}_{2} \mathrm{O}_{3}$ yang terbentuk sedemikian rupa pada permukaan baja karbon sehingga berfungsi sebagai pelindung terhadap korosi baja karbon lebih lanjut. Analisis difraktogram baja karbon yang mendapat perlakuan ini menunjukkan bahwa intensitas relatif dari bidang kisi 110, 200, dan 211 untuk besi hampir tidak mengalami perubahan dibandingkan dengan pola difraksi baja karbon semula, hanya muncul puncak-puncak baru yang berasal dari $\mathrm{Fe}_{3} \mathrm{O}_{4}$ dan $\mathrm{Fe}_{2} \mathrm{O}_{3}$. Keadaan 
ini dapat diacu sebagai kondisi baja karbon dengan laju korosi sangat rendah, yang terlindungi dari serangan korosi lokal ataupun seragam. Dengan mengacu pada diagram potensial - $\mathrm{pH}$ untuk sistem baja karbon dalam larutan berpelarut air yang telah dikonstruksi [12], $\mathrm{pH}$ 8,9 terletak pada daerah pasif dan perlakuan oksigen tersebut diduga menghasilkan pasifasi oleh terbentuknya lapisan tipis oksida besi yang rapat tak berpori pada permukaan baja karbon.

\section{$4 \quad$ Kesimpulan}

Hasil corrosion wheel test dan corrosion bubble test menunjukkan bahwa larutan buffer asetat pada $\mathrm{pH} \sim 3,82-4,12$ yang mengandung $100 \mathrm{mg} / \mathrm{L}$ natrium bikarbonat dan jenuh $\mathrm{CO}_{2}$ pada suhu $65^{\circ} \mathrm{C}$ adalah lingkungan yang memungkinkan baja karbon terkorosi lokal, jenis sumuran, karena pada kondisi ini lapisan kerak karbonat/logam oksida pelindung tercegah dan mendorong terbentuknya besi asetat yang berpori dengan kelarutan tinggi.

Penurunan intensitas difraksi sinar-X yang berasal dari bidang kisi 110 dan 200 fasa ferritik dibandingkan dengan yang menempati bidang kisi 211 atau fasa cementite, yang besarnya sejalan dengan bertambahnya \% pengurangan berat kupon baja karbon terkorosi menunjukkan terjadinya pelarutan selektif besi dalam baja karbon yang menempati kedua bidang kisi tersebut. Diduga hal ini disebabkan karena bidang 211 memiliki \% keterisian atom besi yang paling kecil diantara ketiga bidang itu sehingga memiliki peluang terbesar untuk disisipi atom karbon yang akan memberikan efek perlindungan terhadap atom besi yang berada pada bidang ini untuk tidak terlarut (teroksidasi). Walaupun proses korosi dimulai dari fasa permukaan, namun tampaknya pola difraksi sinar-X (terutama intensitas pada bidang 110, 200, dan 211 kisi besi) dapat dijadikan indikator terjadinya korosi pada baja karbon. Suatu inhibitor korosi yang efektif akan dapat mempertahankan pola difraksi semula.

\section{Ucapan terima kasih}

Penulis mengucapkan terima kasih kepada Dr. Roland De Marco dan Mr. Brian Kinsella beserta staf laboratorium Applied Electrochemistry Research Group, Curtin University of Technology, Western Australia, atas bantuan dan kerjasamanya yang memungkinkan BB melakukan penelitian ini.

\section{Daftar Pustaka}

1. Gunaltun, Y. M., Chevrot, T., Requirement for inhibition of localized corrosion, Corrosion 99, NACE International (1999), paper \# 6.

2. Turnbull, A., Coleman, D., Griffiths, A. J., Francis, P. E., Orkney, L., Effectiveness of Corrosion Inhibitors in Retarding the Rate of Propagation of Localized Corrosion, Corrosion, 59, 250 - 257 (2003). 
3. Schmitt, G., Mueller, M., Papenfuss, M., Strobel-Effertz, E., Understanding localized $\mathrm{CO}_{2}$ Corrosion of carbon steel from physical properties of iron carbonate scales, Corrosion 99, NACE International (1999), paper \# 38.

4. Crolet, J. L., Thevenot, N., Dugstad, A., Role of free acid on the $\mathrm{CO}_{2}$ corrosion of steel, Corrosion 99, NACE International, (1999), paper \# 24.

5. Gunaltun, Y. M., Belghazi, A., Control of top of line corrosion by chemical treatment, Corrosion 2001, NACE International, paper \# 01033.

6. Garsany, Y., Pletcher, D., Hedges, B., The role of acetate in $\mathrm{CO}_{2}$ corrosion of carbon steel; studies related to oil field condition, Corrosion 2003, NACE International, paper \# 03324.

7. Mora - Mendoza, J. L., Turgoose, $\mathrm{S}, \mathrm{Fe}_{3} \mathrm{C}$ influence on the corrosion rate of mild steel in aqueous $\mathrm{CO}_{2}$ systems under turbulent flow conditions. Corrosion Science, 44, 1223-1246, (2002).

8. Gulbrandsen, E., Nyborg, R., Løland, T., Nisancioglu, K., Effect of Steel Microstructure and Composition on Inhibition of $\mathrm{CO}_{2}$ Corrosion, Corrosion 2000, NACE International, (2000), paper\# 00023.

9. Crolet, J. L., Thevenot, N., Nesic, S., Role of Conductive Corrosion Products in the Protectiveness of Corrosion Layers, Corrosion, 54, 194 203. (1998).

10. Park, J. J., Pyun, S. I., Na, K. H., Lee, S. M., Kho, Y. T., Effect of Passivity of the Oxide Film on Low-pH Stress Corrosion Cracking of API 5L X-65 Pipeline Steel in Bicarbonate Solution, Corrosion, 58, 329 336 (2002).

11. Kawai, N., Wada, K., Hirano, H., Application of electrochemical techniques to corrosion control in feedwater and boiler system, Corrosion 2000, NACE International, (2000), paper \# 00408.

12. Bundjali, B., Surdia, N. M., Liang, O. B., Ariwahjoedi, B., Konstruksi Diagram Potensial - $p H$ untuk Baja Karbon dalam Buffer Asetat secara Potensiodinamik Eksperimental, Jurnal Matematika dan Sains, 9, 307 312 (2004) 